Check for updates

Cite this: RSC Adv., 2019, 9, 28312

Received 20th July 2019

Accepted 2nd September 2019

DOI: $10.1039 / c 9 r a 05606 h$

rsc.li/rsc-advances

\section{Facile synthesis of novel 3D flower-like magnetic LaCFe/C composites from ilmenite for efficient phosphate removal from aqueous solution $\dagger$}

\author{
Pengchen Wang, ${ }^{a}$ Andac Armutlulu, ${ }^{\text {b }}$ Wenju Jiang, ${ }^{\text {ac }}$ Bo Lai ${ }^{\mathrm{a}}$ and Ruzhen Xie (iD *a
}

In this study, a novel 3D flower-like La@Fe/C magnetic composite was successfully synthesized by carbothermal reduction of ilmenite via microwave radiation. The physico-chemical properties of the composite were investigated. The results showed that La@Fe/C features a 3D flower-like morphology with an $S_{\mathrm{BET}}$ and $V_{\text {mic }}$ of $114 \mathrm{~m}^{2} \mathrm{~g}^{-1}$ and $0.017 \mathrm{~cm}^{3} \mathrm{~g}^{-1}$, respectively. Zerovalent iron and metal oxides were detected by XRD and XPS on the surface of the adsorbent, which formed as a result of carbothermal reduction of ilmenite using coconut shell-based carbon followed by the introduction of lanthanum. This resultant magnetic La@Fe/C exhibited remarkable phosphate selectivity performance even in the presence of a 50-fold excess of competing ions, which is superior to the pristine ilmenite and coconut activated carbon. Adsorption isotherms and adsorption kinetics fitted well with the Langmuir model and pseudo-second-order model, respectively. A thermodynamic study indicated that the adsorption of phosphate was spontaneous and endothermic. The adsorption-regeneration cyclic experiments of the La@ $\mathrm{Fe} / \mathrm{C}$ composite demonstrated a good level of recyclability. These results indicated that carbothermal reduction of ilmenite followed by the introduction of lanthanum could result in highly efficient and recoverable magnetic particles for the removal of phosphate from wastewater.

\section{Introduction}

Phosphates are essential nutrients for the existence of various life forms. However, excessive release of phosphate into water bodies can trigger the deterioration of water quality, collapse of the aquatic ecosystem, or even algae blooms because of eutrophication. ${ }^{1}$ In the past few decades, various methods have been investigated for the removal of excessive phosphate from the water bodies. Adsorption has often been proposed as a promising means for phosphate removal due to its several favorable characteristics including (i) simple design, (ii) ease of operation, and (iii) high removal efficiency even at low phosphate concentration. $^{2}$ Various types of adsorbents such as biomass, activated carbon, metal oxide nanoparticles and hydrogel have been explored to remove phosphate from water, ${ }^{3,4}$ yet, enhancing the phosphate adsorption capacity and recyclability of the adsorbents remained as two important challenges to be overcome.

${ }^{a}$ College of Architecture and Environment, Sichuan University, Chengdu 610065, P. R. China. E-mail: xieruzhen@scu.edu.cn; Fax: +86-28-8540-3016; Tel: +86-28-8540-7800 ${ }^{b}$ Department of Mechanical and Process Engineering, ETH Zurich, Leonhardstrasse 27, 8092, Zurich, Switzerland

${ }^{c}$ National Engineering Research Center for Flue Gas Desulfurization, Chengdu 610065, P. R. China

$\dagger$ Electronic supplementary information (ESI) available. See DOI: 10.1039/c9ra05606h
Among different types of oxides and hydroxides of metals tested, those of $\mathrm{Fe}, \mathrm{Al}, \mathrm{La}$ and $\mathrm{Ca}$ have been regarded as effective adsorbents for the removal of phosphate owing to their high phosphate binding capacity. ${ }^{5}$ In particular, lanthanum (La) has attracted special attention, since it is highly active in binding phosphate and forming environmentally friendly lanthanumphosphate complex, which is highly insoluble $(\mathrm{pK}=26.16) \mathbf{. 4}^{\mathbf{4 , 6}}$ Therefore, lanthanum has often been preferred as a loading agent to enhance the removal of phosphate from aqueous solutions. Various La loaded porous adsorbent such as Laloaded mesoporous silica, ${ }^{7}$ La-loaded activated fiber ${ }^{8}$ and Laloaded zeolite ${ }^{9}$ have been proven to be favorable for improving phosphate uptake capacity. However, in spite of their promising adsorption capacity towards phosphate, their practical application is rather limited due to the difficulties encountered in separating these adsorbents from water.

Recently, coatings of magnetic iron or its (hydr)oxides on lanthanum have been offered as an effective means to enable the rapid magnetic separation of the adsorbents from aqueous solutions. Researchers have demonstrated that $\mathrm{Fe}_{3} \mathrm{O}_{4}$-coated lanthanum $\left(\mathrm{La}(\mathrm{OH})_{3} / \mathrm{Fe}_{3} \mathrm{O}_{4}\right)$ exhibited higher adsorption capacity toward phosphate compared to pure $\mathrm{Fe}_{3} \mathrm{O}_{4} \cdot{ }^{10}$ Among iron-based nanoparticles, zerovalent iron (nZVI) exhibited significantly higher adsorptive removal capacity towards phosphate than other adsorbents, which is caused by the synergetic effect of precipitation and chemical adsorption during the removal of phosphate. ${ }^{\mathbf{1 1}}$ However, nZVI has certain 
shortcomings, including ease of aggregation and oxidation, which adversely affect its adsorptive removal performance. ${ }^{12}$ To alleviate these detrimental effects, stabilization of nZVI on carriers that are compatible with the adsorptive removal process, i.e., activated carbon and activated carbon fiber, have been proposed as an effective strategy that not only reduces nZVI agglomeration, but also prevents its oxidation. ${ }^{12}$ However, the stabilization of nZVI on carriers typically involves relatively burdensome multiple-step protocols, such as coating, reducing, washing and drying processes, which would result in a higher production cost. On the contrary, one-step pyrolysis of iron oxide with carbon possesses a greener and economically feasible way to produce affordable nZVI for environmental remediation.

This study shows first demonstration of preparing nZVI loaded particles through a one-step carbothermal reduction assisted by microwave radiation, whereby low-cost ilmenite is used as a raw material. Ilmenite is an abundant natural magnetic ore with chemical formula of $\mathrm{FeTiO}_{3}{ }^{13}$ After carbothermal reduction of ilmenite by coconut activated carbon (AC) via microwave radiation, novel magnetic nZVI-based particles with flower-like morphologies were obtained. To further improve the phosphate adsorption capacity, lanthanum was introduced into the nZVI-based particles. The physico-chemical properties of the resultant adsorbents were characterized. The influence of various parameters such as lanthanum impregnation ratio, adsorbent dosage, $\mathrm{pH}$ and contact time on phosphate removal were investigated in a systematic fashion and discussed in detail. Furthermore, the kinetics and thermodynamics of the adsorption process were examined. Finally, the recyclability of the adsorbents synthesized was evaluated.

\section{Materials and methods}

\subsection{Materials}

The ilmenite from Sichuan province of China was used as raw material to prepare adsorbents, which mainly consisted of (wt\%): O (45.1), Fe (21.7), Ti (20.8), C (3.4), Mg (2.9), Si (2.8), Al (1.5), S (0.7), Ca (0.6), Mn (0.4), and Na (0.1). The elemental composition of the coconut activated carbon was as follows (wt\%): $\mathrm{C}(85.6), \mathrm{H}(1.5), \mathrm{N}(0.5), \mathrm{O}(12.4)$. Chemical reagents such as $\mathrm{LaCl}_{3} \cdot 9 \mathrm{H}_{2} \mathrm{O}, \mathrm{KH}_{2} \mathrm{PO}_{4}, \mathrm{NaOH}$ and $\mathrm{HCl}$ were of analytical reagent grade and used as received without further purification.

\subsection{Preparation of adsorbents}

For the preparation of the adsorbents, raw materials, i.e., ilmenite and coconut activated carbon, were dried, grinded and sieved pass through a 200-mesh screen. $15 \mathrm{~g}$ of the mixed sample with a ratio of $m_{\text {Ilmenite }}: m_{\mathrm{AC}}=4: 1$ was then activated at $600 \mathrm{~W}$ for $10 \mathrm{~min}$ in the microwave oven under $\mathrm{N}_{2}$ atmosphere. The resultant particles were designated as $\mathrm{Fe} / \mathrm{C}$ precursor, and the magnetic particles separated from $\mathrm{Fe} / \mathrm{C}$ precursor using magnet were named as magnetic precursor. For the fabrication of lanthanum-loaded $\mathrm{Fe} / \mathrm{C}$ composites, $100 \mathrm{~mL}$ certain concentration $\mathrm{LaCl}_{3}$ solution was added to $2 \mathrm{~g}$ of $\mathrm{Fe} / \mathrm{C}$ precursor, and then $0.1 \mathrm{~mol} \mathrm{~L}^{-1} \mathrm{NaOH}$ solution was introduced dropwise until the final $\mathrm{pH}$ reached 10.0. The final mixture was stirred at $333 \mathrm{~K}$ for $1 \mathrm{~h} .{ }^{14}$ Thereafter, the slurry was dried at $378 \mathrm{~K}$, followed by activation at $300 \mathrm{~W}$ for $2 \mathrm{~min}$ in the microwave oven under $\mathrm{N}_{2}$ atmosphere. Upon cooling to room temperature, the samples were crushed and sieved through a 200-mesh screen for adsorption tests. The sample produced with impregnated lanthanum was labeled as $\mathrm{La}^{x} @ \mathrm{Fe} / \mathrm{C}$, where $x$ refers to the impregnating concentration of La. The sample $\mathrm{La}^{x} @ \mathrm{Fe} / \mathrm{C}$ after phosphate adsorption was named La $@ \mathrm{Fe} / \mathrm{C}-\mathrm{A}$.

\subsection{Phosphate adsorption experiments}

Phosphate solution was prepared by dissolving analytical grade anhydrous potassium dihydrogen phosphate $\left(\mathrm{KH}_{2} \mathrm{PO}_{4}\right)$ in distilled water. The phosphate adsorption experiments were carried out in sealed conical flasks with $50 \mathrm{~mL}$ of $10 \mathrm{mg} \mathrm{L}^{-1} \mathrm{P}$. The effect of lanthanum impregnation ratio, adsorbent dosage (1-8 $\left.\mathrm{g} \mathrm{L}^{-1}\right), \mathrm{pH}(3-11)$ and contact time (0-180 min) was studied. After the adsorption process, the suspension was filtered through a $0.45 \mu \mathrm{m}$ membrane, and the remaining phosphate concentration was determined according to the molybdenum blue spectrophotometric method (UV/Vis spectrophotometer at $\left.\lambda_{\max }=700 \mathrm{~nm}\right){ }^{8}{ }^{8}$ The adsorption experiments were carried out three times, and the mean values of the tests were reported with relative standard deviation (RSD) below $0.52 \%$.

The removal efficiency $(\eta)$ of phosphate and the adsorption capacity $\left(q_{t}\right)$ of the adsorbent were calculated according to eqn (1) and (2), respectively:

$$
\begin{gathered}
\eta=\frac{C_{0}-C_{t}}{C_{0}} \times 100 \% \\
q_{t}=\frac{\left(C_{0}-C_{t}\right) \times V}{M}
\end{gathered}
$$

where $C_{0}\left(\mathrm{mg} \mathrm{L}^{-1}\right)$ and $C_{t}\left(\mathrm{mg} \mathrm{L}^{-1}\right)$ are the concentrations of the phosphate initially and at time $t(\mathrm{~min})$, respectively; $\eta(\%)$ is the removal efficiency of phosphate; $V(\mathrm{~L})$ is the volume of phosphate solution; and $M(\mathrm{~g})$ is the mass of the adsorbent.

The equilibrium adsorption capacity $\left(q_{\mathrm{e}}, \mathrm{mg}^{-1}\right)$ was determined as eqn (3):

$$
q_{\mathrm{e}}=\frac{\left(C_{0}-C_{\mathrm{e}}\right) \times V}{M}
$$

where $C_{\mathrm{e}}\left(\mathrm{mg} \mathrm{L}^{-1}\right)$ is the equilibrium concentration of phosphate.

The influence of coexisting ions on the phosphate removal, such as $\mathrm{Ca}^{2+}\left(60-220 \mathrm{mg} \mathrm{L}^{-1}\right), \mathrm{Cl}^{-}\left(50-300 \mathrm{mg} \mathrm{L}^{-1}\right), \mathrm{NO}_{3}{ }^{-}(50-$ $\left.300 \mathrm{mg} \mathrm{L}^{-1}\right), \mathrm{SO}_{4}{ }^{2-}\left(50-300 \mathrm{mg} \mathrm{L}{ }^{-1}\right)$, and $\mathrm{CO}_{3}{ }^{2-}(50-$ $300 \mathrm{mg} \mathrm{L}^{-1}$ ) were evaluated in batch experiments with phosphate concentration of $10 \mathrm{mg} \mathrm{L}^{-1}$. The La@Fe/C after phosphate adsorption were calcined at $673 \mathrm{~K}$, washed, and dried for further regeneration tests.

The mechanism for phosphate adsorption onto the adsorbents was studied by fitting the kinetic data with pseudo-firstorder model, pseudo-second-order model and intra-particlediffusion model (eqn (4)-(6)): ${ }^{15-17}$

$$
\ln \left(q_{\mathrm{e}}-q_{t}\right)=\ln q_{\mathrm{e}}-k_{1} t
$$




$$
\begin{aligned}
& \frac{t}{q_{t}}=\frac{1}{k_{2} q_{\mathrm{e}}^{2}}+\frac{1}{q_{\mathrm{e}}} t \\
& q_{t}=k_{\mathrm{id}} t^{1 / 2}+C
\end{aligned}
$$

where $q_{\mathrm{e}}$ and $q_{t}\left(\mathrm{mg} \mathrm{g}^{-1}\right)$ are the respective adsorption capacities at equilibrium and at time " $t$ " $(\mathrm{min}) ; k_{1}, k_{2}$ and $k_{\mathrm{id}}$ are the rate constants of pseudo-first-order model, pseudo-second-order model and intra-particle-diffusion model, respectively, and $C$ is a constant related to the extent of the boundary layer thickness.

Three widely used isotherms including Langmuir, Freundlich and Temkin models were applied to fit the experimental data for adsorbing phosphate onto adsorbent (eqn (7)-(9)). ${ }^{\mathbf{1 8 - 2 0}}$

$$
\begin{gathered}
\frac{C_{\mathrm{e}}}{q_{\mathrm{e}}}=\frac{C_{\mathrm{e}}}{q_{\mathrm{m}}}+\frac{1}{k_{\mathrm{L}} q_{\mathrm{m}}} \\
\ln q_{\mathrm{e}}=\ln k_{\mathrm{F}}+\frac{1}{n} \ln C_{\mathrm{e}} \\
q_{\mathrm{e}}=B_{\mathrm{T}} \ln A_{\mathrm{T}}+B_{\mathrm{T}} \ln \left(C_{\mathrm{e}}\right)
\end{gathered}
$$

where $q_{\mathrm{m}}\left(\mathrm{mg} \mathrm{g}^{-1}\right)$ and $k_{\mathrm{L}}\left(\mathrm{L} \mathrm{mg}^{-1}\right)$ are Langmuir constants related to the adsorption capacity and the adsorption rate, respectively; $k_{\mathrm{F}}\left(\left(\mathrm{mg} \mathrm{g}^{-1}\right)(\mathrm{L} \mathrm{mg})^{-1 / n}\right)$ and $n$ are the constants and a measure of the adsorption intensity, respectively. $B_{\mathrm{T}}=R T / b$, where $b\left(\mathrm{~J} \mathrm{~mol}^{-1}\right), A_{\mathrm{T}}\left(\mathrm{L} \mathrm{mg}^{-1}\right), R\left(8.314 \mathrm{~J} \mathrm{~mol}^{-1} \mathrm{~K}^{-1}\right)$ and $T(\mathrm{~K})$ are the Temkin constant related to the heat of adsorption, equilibrium binding constant, gas constant and absolute temperature, respectively.

Thermodynamic parameters including enthalpy $\left(\Delta H^{0}\right)$, entropy $\left(\Delta S^{0}\right)$ and free energy $\left(\Delta G^{0}\right)$ were calculated using the eqn (10) and (11): ${ }^{21}$

$$
\begin{aligned}
& \ln k_{\mathrm{d}}=\frac{\Delta S^{0}}{R}-\frac{\Delta H^{0}}{R T} \\
& \Delta G^{0}=-R T \ln k_{\mathrm{d}}
\end{aligned}
$$

where $k_{\mathrm{d}}$ is the distribution coefficient; $\Delta S^{0}\left(\mathrm{~kJ} \mathrm{~mol}^{-1} \mathrm{~K}^{-1}\right)$ is the standard entropy; $\Delta H^{0}\left(\mathrm{~kJ} \mathrm{~mol}^{-1}\right)$ is the standard enthalpy; $R$ (8.314 $\mathrm{J} \mathrm{mol}^{-1} \mathrm{~K}^{-1}$ ) is the gas constant and $T(\mathrm{~K})$ is the absolute temperature.

\subsection{Characterization of adsorbents}

$\mathrm{N}_{2}$ adsorption-desorption isotherm of samples was measured at $77 \mathrm{~K}$ using the surface area analyzer (ASAP 2460, Norcross, $\mathrm{GA})$. The specific surface area $\left(S_{\mathrm{BET}}\right)$, total pore volume $\left(V_{\text {tot }}\right)$, mesopore volume $\left(V_{\text {mes }}\right)$, micropore volume $\left(V_{\text {mic }}\right)$, and pore size distribution were obtained from the $\mathrm{N}_{2}$ adsorptiondesorption isotherms using the Brunauer-Emmett-Teller (BET) equation, $\mathrm{N}_{2}$ adsorption amount at the maximum relative pressure, Barrett-Joyner-Halenda (BJH) method, $t$-plot method, and density functional theory (DFT) method, respectively.

The crystallinity and phase identification of adsorbents were determined by XRD (X-Pert PRO MPD, Panalytical, NL) with Cu
$\mathrm{K} \alpha$ as the radiation source under $36 \mathrm{KV}$ with $2 \theta$ range of $10-80^{\circ}$. The surface chemistry was determined by an X-ray photoelectron spectroscopy (XPS) (XSAM-800, KRATOS, UK) with Al (1486.6 eV) under ultra-high vacuum at $12 \mathrm{kV}$ and $15 \mathrm{~mA}$.

Fourier Transforms Infrared Spectroscopy (FTIR) characterization was carried out with a spectrometer (Tensor 27 spectrometer, FTIR-6700, Nicolet, USA) in the range of 4000$400 \mathrm{~cm}^{-1}$ with a resolution of $4 \mathrm{~cm}^{-1}$. The Scanning Electron Microscopy (SEM) measurement was carried out using SEM (JEOL, JSM-7500 F, Japan). $\mathrm{pH}$ point of zero charge ( $\mathrm{pH}_{\mathrm{PZC}}$ ) was measured by the method described by Moharami and Jalali to investigate the total surface charge of the adsorbents. ${ }^{22}$

\section{Results and discussion}

\subsection{Characterization of the adsorbents}

3.1.1 Textural properties. The textural properties of the absorbents synthesized are shown in Table 1, which were calculated on the basis of their $\mathrm{N}_{2}$ adsorption-desorption isotherms. $\mathrm{N}_{2}$ isotherms (Fig. $\mathrm{S} 1$ in ESI $\dagger$ ) showed that the pristine ilmenite had no obvious porosity, while coconut AC and La@Fe/C had hierarchical pore structure with obvious hysteresis loop (Fig. S1b and $\mathrm{d} \dagger$ ). ${ }^{23}$ As can be seen from Table 1, the specific surface area $\left(S_{\mathrm{BET}}\right)$ of pristine ilmenite, coconut $\mathrm{AC}$, and $\mathrm{Fe} / \mathrm{C}$ precursor were $0.3 \mathrm{~m}^{2} \mathrm{~g}^{-1}, 1590 \mathrm{~m}^{2} \mathrm{~g}^{-1}$, and $270 \mathrm{~m}^{2} \mathrm{~g}^{-1}$, respectively. After La modification, the $S_{\mathrm{BET}}$ of $\mathrm{La}^{0.001} @ \mathrm{Fe} / \mathrm{C}$, $\mathrm{La}^{0.005} @ \mathrm{Fe} / \mathrm{C}, \mathrm{La}^{0.06} @ \mathrm{Fe} / \mathrm{C}$ and $\mathrm{La}^{0.12} @ \mathrm{Fe} / \mathrm{C}$ were $106 \mathrm{~m}^{2} \mathrm{~g}^{-1}$, $114 \mathrm{~m}^{2} \mathrm{~g}^{-1}, 115 \mathrm{~m}^{2} \mathrm{~g}^{-1}$, and $117 \mathrm{~m}^{2} \mathrm{~g}^{-1}$, respectively, all of which are substantially smaller than the Fe/C precursor. The reduction of the $S_{\mathrm{BET}}$ after La doping may possibly result from the formation of aggregated $\mathrm{La} / \mathrm{Fe}$-nanocomposites leading to an increased particle size. ${ }^{\mathbf{1 0}}$ The micropore volume $\left(V_{\text {mic }}\right)$ and mesopore volume $\left(V_{\text {mes }}\right)$ of La@Fe/C (in range of 0.011-0.237 $\mathrm{cm}^{3} \mathrm{~g}^{-1}$ and $0.041-0.167 \mathrm{~cm}^{3} \mathrm{~g}^{-1}$, respectively) are much higher than that of pristine ilmenite $\left(0.00007\right.$ and $0.00119 \mathrm{~cm}^{3} \mathrm{~g}^{-1}$, respectively), suggesting that large amount of porosities were formed on La@Fe/C during carbothermal reduction of ilmenite.

Table 1 further compares the adsorption performance of the mentioned adsorbents with a concentration of $1 \mathrm{~g} \mathrm{~L}^{-1}$ tested in $10 \mathrm{mg} \mathrm{L}^{-1}$ phosphate solution. It was obvious that both AC and ilmenite exhibited relatively low phosphate adsorption capacity, with $q_{\mathrm{e}}$ value of $2.73 \mathrm{mg} \mathrm{g}^{-1}$ and $0.79 \mathrm{mg} \mathrm{g}^{-1}$, respectively. However, upon carbothermal reduction of ilmenite, the resulting $\mathrm{Fe} / \mathrm{C}$ precursor exhibited a substantially higher adsorption capacity (i.e., $q_{\mathrm{e}}=5.61 \mathrm{mg} \mathrm{g}^{-1}$ ), which could be attributed to the generation of active sites, i.e., nZVI $\left(\mathrm{Fe}^{0}\right)$ and $\mathrm{Fe}_{2} \mathrm{O}_{3}$, for phosphate removal. It can also be seen that although $\mathrm{La}^{0.12}$ @Fe/C has the lowest microporosity, it possesses the highest adsorption capacity toward phosphate, which is possibly linked to the higher lanthanum loading providing more active sites on $\mathrm{La}^{0.12} @ \mathrm{Fe} / \mathrm{C}$ for binding phosphate. An interesting point to note is that $\mathrm{La}^{0.005} @ \mathrm{Fe} / \mathrm{C}\left(q_{\mathrm{e}}=7.20 \mathrm{mg} \mathrm{g}^{-1}\right)$ showed higher phosphate uptake capacity than $\mathrm{La}^{0.06} @ \mathrm{Fe} / \mathrm{C}\left(q_{\mathrm{e}}=6.43 \mathrm{mg} \mathrm{g}^{-1}\right)$, which might be related to the higher microporosity of $\mathrm{La}^{0.005} @ \mathrm{Fe} / \mathrm{C}\left(V_{\text {mic }}=0.017 \mathrm{~cm}^{3} \mathrm{~g}^{-1}\right)$ as compared to $\mathrm{La}^{0.06} @ \mathrm{Fe} /$ $\mathrm{C}\left(V_{\text {mic }}=0.011 \mathrm{~cm}^{3} \mathrm{~g}^{-1}\right)$. Since the hydrated radius of phosphate species (i.e., $\mathrm{H}_{2} \mathrm{PO}_{3}{ }^{-}$, $\mathrm{PO}_{4}{ }^{3-}$, and $\mathrm{HPO}_{4}{ }^{2-}$ ) is less than 
Table 1 Textural properties of the adsorbents ${ }^{a}$

\begin{tabular}{|c|c|c|c|c|c|c|}
\hline Adsorbent & $S_{\mathrm{BET}}\left(\mathrm{m}^{2} \mathrm{~g}^{-1}\right)$ & $V_{\text {tot }}\left(\mathrm{cm}^{3} \mathrm{~g}^{-1}\right)$ & $V_{\text {mic }}\left(\mathrm{cm}^{3} \mathrm{~g}^{-1}\right)$ & $V_{\text {mes }}\left(\mathrm{cm}^{3} \mathrm{~g}^{-1}\right)$ & $D_{\text {mean }}(\mathrm{nm})$ & $q_{\mathrm{e}}\left(\mathrm{mg} \mathrm{g}^{-1}\right)$ \\
\hline Ilmenite & 0.3 & 0.00147 & 0.00007 & 0.00119 & 30.25 & 0.79 \\
\hline $\mathrm{AC}$ & 1590 & 1.437 & 0.237 & 0.965 & 6.02 & 2.73 \\
\hline $\mathrm{Fe} / \mathrm{C}$ precursor & 270 & 0.241 & 0.039 & 0.164 & 5.67 & 5.61 \\
\hline $\mathrm{La}^{0.001} @ \mathrm{Fe} / \mathrm{C}$ & 106 & 0.102 & 0.017 & 0.071 & 6.11 & 7.10 \\
\hline $\mathrm{La}^{0.005} @ \mathrm{Fe} / \mathrm{C}$ & 114 & 0.108 & 0.017 & 0.075 & 5.88 & 7.20 \\
\hline $\mathrm{La}^{0.06} @ \mathrm{Fe} / \mathrm{C}$ & 115 & 0.113 & 0.011 & 0.089 & 4.89 & 6.43 \\
\hline $\mathrm{La}^{0.12} @ \mathrm{Fe} / \mathrm{C}$ & 117 & 0.176 & 0 & 0.167 & 6.78 & 9.99 \\
\hline $\mathrm{La}^{0.005} @ \mathrm{Fe} / \mathrm{C}-\mathrm{A}$ & 76 & 0.074 & 0.011 & 0.052 & 6.17 & - \\
\hline
\end{tabular}

$\mathrm{La}^{0.005}$ @Fe/C-A

0.011

6.17

${ }^{a} S_{\mathrm{BET}}$, BET surface area; $V_{\text {tot }}$, total pore volume; $V_{\mathrm{mes}}$, mesopore volume; $V_{\text {mic }}$, micropore volume; $D_{\text {mean }}$, average pore diameter; $q_{\mathrm{e}}$, adsorption capacities toward $10 \mathrm{mg} \mathrm{L}^{-1}$ phosphate; La ${ }^{0.005} @ \mathrm{Fe} / \mathrm{C}-\mathrm{A}: \mathrm{La}^{0.005} @ \mathrm{Fe} / \mathrm{C}$ after phosphate adsorption.

$0.339 \mathrm{~nm}$, micropore was favored for the removal of phosphate. ${ }^{24}$ Although La ${ }^{0.12} @ \mathrm{Fe} / \mathrm{C}$ exhibited the highest phosphate removal capacity, to minimize the use of La chemicals, $\mathrm{La}^{0.005} @ \mathrm{Fe} / \mathrm{C}$ particles was selected for further studies.

Fig. 1 showed the SEM images for ilmenite, precursor (i.e., $\mathrm{Fe} / \mathrm{C}$ ), and the adsorbent of interest before and after phosphate adsorption (i.e., $\mathrm{La}^{0.005} @ \mathrm{Fe} / \mathrm{C}$ and $\mathrm{La}^{0.005} @ \mathrm{Fe} / \mathrm{C}-\mathrm{A}$ ). It can be seen that seldom pores can be observed on the pristine ilmenite, while the $\mathrm{Fe} / \mathrm{C}$ precursor exhibited a porous structure with flower-like morphology (Fig. 1d-f). Further loading of La did not destruct the 3D flower-like morphology (Fig. 1g-i). Such morphologies with submicron level pore sizes are favorable for adsorption purposes. Fig. 1g-i demonstrate that $\mathrm{La}^{0.005} @ \mathrm{Fe} / \mathrm{C}-\mathrm{A}$ could maintain its 3D flower-like structure after phosphate adsorption. The nm-sized lamellar structure found on the $\mathrm{La}^{0.005}$ @Fe/C-A can be ascribed to the formation of insoluble lanthanum-phosphate complex and iron-phosphate complex on the surface of $\mathrm{La}^{0.005} @ \mathrm{Fe} / \mathrm{C}$. The porous morphology of $\mathrm{La}^{0.005} @ \mathrm{Fe} / \mathrm{C}$ did not undergo a significant change upon phosphate adsorption (Fig. 1e vs. Fig. 1h).

3.1.2 XRD analysis. XRD patterns of ilmenite, $\mathrm{Fe} / \mathrm{C}$ precursor, magnetic precursor, $\mathrm{La}^{0.005} @ \mathrm{Fe} / \mathrm{C}$ and $\mathrm{La}^{0.005} @ \mathrm{Fe} /$ C-A are shown in Fig. 2. The detected peaks on Fig. $2 \mathrm{a}$ at $2 \theta=$ $23.825^{\circ}, 32.588^{\circ}, 35.257^{\circ}, 40.323^{\circ}, 48.766^{\circ}, 53.136^{\circ}, 61.594^{\circ}$, $63.269^{\circ}$ and $70.304^{\circ}$ for ilmenite are assigned to $\mathrm{FeTiO}_{3}$ (JCPDS 71-1140).

New peaks appeared following the microwave radiation treatment, as shown in Fig. $2 \mathrm{~b}-\mathrm{d}$, which resulted from the carbothermal reduction reactions between ilmenite and activated carbon. As can be seen in Fig. $2 \mathrm{~b}-\mathrm{d}$, the new peaks at $2 \theta=$ $23.802^{\circ}, 35.305^{\circ}, 44.504^{\circ}, 48.532^{\circ}, 53.420^{\circ}, 61.694^{\circ}, 63.539^{\circ}$, $75.037^{\circ}$ and $76.628^{\circ}$, and $2 \theta=32.802^{\circ}, 35.193^{\circ}, 44.879^{\circ}, 61.751^{\circ}$
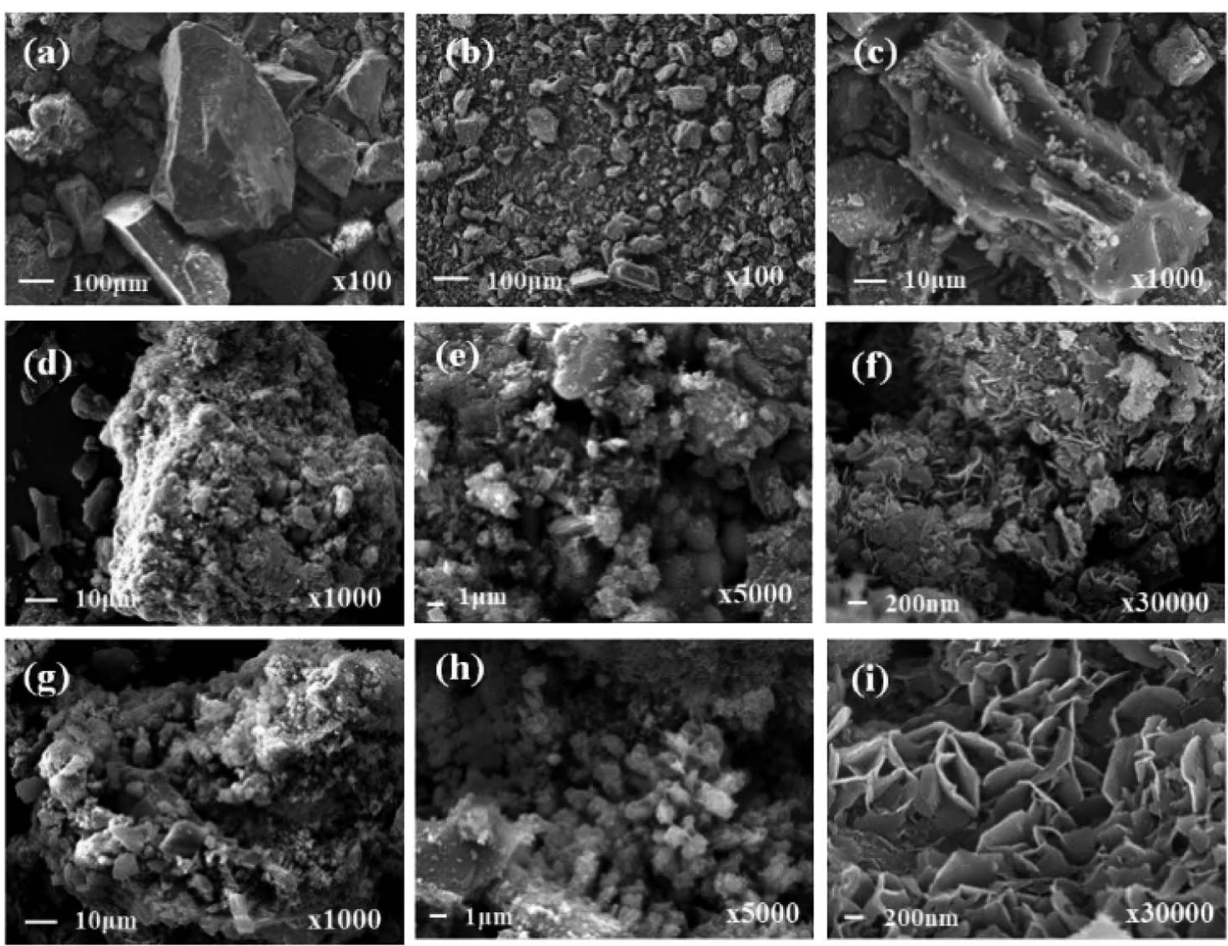

Fig. 1 SEM for (a) ilmenite, (b, c) Fe/C precursor, (d-f) La ${ }^{0.005} \mathrm{aFe} / \mathrm{C}$, and (g-i) La ${ }^{0.005} \mathrm{aFe} / \mathrm{C}-\mathrm{A}$. 
and $70.236^{\circ}$ were corresponding to $\mathrm{TiO}_{2}$ (JCPDS 46-1237) and $\mathrm{Fe}_{2} \mathrm{O}_{3}$ (JCPDS 16-0653), respectively.

Furthermore, the characteristic diffraction peaks in Fig. 2d and e at $2 \theta=25.328^{\circ}, 44.634^{\circ}, 59.955^{\circ}$ can be indexed to $\mathrm{La}_{2} \mathrm{O}_{3}$ (JCPDS 40-1281). $\mathrm{Fe}^{0}$ was found at $2 \theta=44.669^{\circ}$ and $65.000^{\circ}$ (JCPDS 16-0696) on the XRD patterns of magnetic precursor, which confirmed the formation of nZVI via carbothermal reduction of ilmenite. Moreover, $\mathrm{Fe}_{12} \mathrm{LaO}_{19}$ was also detected at $2 \theta=35.164^{\circ}, 40.605^{\circ}, 55.294^{\circ}$ and $56.402^{\circ}$ (JCPDS 13-0474), indicating that the La-Fe nanocomposites were also formed during microwave heating. These results are in line with the studies showing that $\mathrm{TiO}_{2}$ and $\mathrm{Fe}_{2} \mathrm{O}_{3}$ can be obtained by hightemperature activation of ilmenite. ${ }^{25} \mathrm{TiO}_{2}$ formed in the adsorbent did not undergo further structural changes, despite the extremely high reaction temperature. ${ }^{26,27}$ The diffraction peaks of $\mathrm{Fe}^{0}$ were not obvious except for the XRD pattern of the magnetic precursor, which could originate from the small grain size and good dispersion of $\mathrm{Fe}^{0}$ on $\mathrm{La}^{0.005} @ \mathrm{Fe} / \mathrm{C}$.

After adsorbing phosphate, new peaks were observed on $\mathrm{La}^{0.005} @ \mathrm{Fe} / \mathrm{C}-\mathrm{A}$ (Fig. 2e). The peaks located at $2 \theta=25.281^{\circ}$ and $40.264^{\circ}$ can be ascribed to $\mathrm{FePO}_{4}$ (JCPDS 31-0647) and peaks at $2 \theta=25.281^{\circ}, 48.375^{\circ}, 51.909^{\circ}, 53.210^{\circ}$ and $56.027^{\circ}$ belonged to $\mathrm{LaPO}_{4}$ (JCPDS 04-0635). These detected peaks of $\mathrm{FePO}_{4}$ and $\mathrm{LaPO}_{4}$ on the surface of $\mathrm{La}^{0.005} @ \mathrm{Fe} / \mathrm{C}-\mathrm{A}$ are indicative of the reactions between phosphate and metal/metal oxides during the adsorption process. Thus, the mechanism between phosphate and metal/metal oxides in $\mathrm{La}^{0.005} @ \mathrm{Fe} / \mathrm{C}$ during the adsorption process could be proposed as ion exchange or metal phosphate precipitation process as shown in eqn (12).

$$
\mathrm{La}^{3+}+\mathrm{Fe}^{3+}+2 \mathrm{PO}_{4}{ }^{3-} \rightarrow \mathrm{LaPO}_{4} \downarrow+\mathrm{FePO}_{4} \downarrow
$$

3.1.3 XPS analysis. XPS was used to analyze the elemental composition and the chemical bond state on the surface of $\mathrm{La}^{0.005} @ \mathrm{Fe} / \mathrm{C}$ and $\mathrm{La}^{0.005} @ \mathrm{Fe} / \mathrm{C}-\mathrm{A}$. The relative content of elements in adsorbent were: C $62.39 \mathrm{wt} \%$, O $23.54 \mathrm{wt} \%$, Fe $8.08 \mathrm{wt} \%$, La $4.87 \mathrm{wt} \%$, Ti $1.12 \mathrm{wt} \%$. The XPS spectra of magnetic precursor were also analyzed to clarify the status of iron in the composites. As shown in Fig. 3a, the respective binding energies of $\mathrm{Ti} 2 \mathrm{p}_{3 / 2}$ and $\mathrm{Ti} 2 \mathrm{p}_{1 / 2}$ were found to be $460.5 \mathrm{eV}$ and $466.3 \mathrm{eV}$ for $\mathrm{La}^{0.005} @ \mathrm{Fe} / \mathrm{C}$.

After phosphate adsorption, no significant change was observed in the binding energy of Ti on La ${ }^{0.005} @ \mathrm{Fe} / \mathrm{C}-\mathrm{A}$. Moreover, the difference between the binding energies of Ti $2 \mathrm{p}_{3 / 2}$ and Ti $2 \mathrm{p}_{1 / 2}$ on the spectra of $\mathrm{La}^{0.005} @ \mathrm{Fe} / \mathrm{C}$ and $\mathrm{La}^{0.005} @ \mathrm{Fe} / \mathrm{C}-\mathrm{A}$ was equal to $5.8 \pm 0.1 \mathrm{eV}$, which might point to the presence of $\mathrm{TiO}_{2}$ on $\mathrm{La}^{0.005} @ \mathrm{Fe} / \mathrm{C}$ and $\mathrm{La}^{0.005} @ \mathrm{Fe} / \mathrm{C}-\mathrm{A} .{ }^{28-30}$ The fact that $\mathrm{TiO}_{2}$ can still be detected in $\mathrm{La}^{0.005} @ \mathrm{Fe} / \mathrm{C}-\mathrm{A}$ after phosphate adsorption indicates that $\mathrm{TiO}_{2}$ did not react with phosphorus to form complexes.

The binding energy of $\mathrm{Fe} 2 \mathrm{p}_{3 / 2}$ with peaks for $\mathrm{Fe}(\mathrm{III}), \mathrm{Fe}(\mathrm{II})$ and $\mathrm{Fe}(0)$ appeared at 713.5-714.1, 711.5-712.0 and $708.2 \mathrm{eV}$, respectively, and the $\mathrm{Fe} 2 \mathrm{p}_{1 / 2}$ peaks for $\mathrm{Fe}(\mathrm{III})$ and $\mathrm{Fe}(\mathrm{II})$ centered at 725.8-726.0 and 717.0-717.4 eV, respectively. ${ }^{31,32}$ Thus, the presence of $\mathrm{Fe}^{3+}, \mathrm{Fe}^{2+}$ and $\mathrm{Fe}^{0}$ in samples confirmed that $\mathrm{FeTiO}_{3}$ in ilmenite was reduced by $\mathrm{C}$ in activated carbon, and the formation of nZVI took place under microwave radiation. Moreover, the binding energy peak of $\mathrm{La} 3 \mathrm{~d}_{5 / 2}$ at around $838.0 \mathrm{eV}$ and $\mathrm{La} 3 \mathrm{~d}_{3 / 2}$ at $854.0 \mathrm{eV}$ indicated the existence of $\mathrm{La}^{3+}$ in $\mathrm{La}_{2} \mathrm{O}_{3},{ }^{33}$ which suggests the formation of $\mathrm{La}_{2} \mathrm{O}_{3}$ via the calcination of $\mathrm{LaCl}_{3}$ at $673 \mathrm{~K}$. Following phosphate adsorption, slight changes were observed in the binding energies for Fe $2 \mathrm{p}$ and La 3d of $\mathrm{La}^{0.005} @ \mathrm{Fe} / \mathrm{C}$ as shown in Fig. 3b and c, which suggest that Fe and La were involved in the phosphate removal process. These results were also confirmed by the XRD analysis, whereby $\mathrm{FePO}_{4}$ and $\mathrm{LaPO}_{4}$ could be detected in the spectra of $\mathrm{La}^{0.005}$ @Fe/C-A (Fig. 2e).

3.1.4 FTIR analysis. Fig. 4 showed the FTIR spectra of $\mathrm{La}^{0.005} @ \mathrm{Fe} / \mathrm{C}$ before and after phosphate adsorption. No obvious difference was observed between the bands of $\mathrm{La}^{0.005} @ \mathrm{Fe} / \mathrm{C}$ and La ${ }^{0.005} @ \mathrm{Fe} / \mathrm{C}-\mathrm{A}$. Three characteristic bands at $3440 \mathrm{~cm}^{-1}, 1068 \mathrm{~cm}^{-1}$ and $560 \mathrm{~cm}^{-1}$ were found for both $\mathrm{La}^{0.005} @ \mathrm{Fe} / \mathrm{C}$ and La ${ }^{0.005} @ \mathrm{Fe} / \mathrm{C}-\mathrm{A}$. The peak at about $3440 \mathrm{~cm}^{-1}$ can be assigned to the $\mathrm{O}-\mathrm{H}$ stretching vibration, which was indicative of the presence of hydroxylic, carboxylic, and phenolic groups (including hydrogen bonding) in the coconut AC matrix. ${ }^{34}$ The peak at $1068 \mathrm{~cm}^{-1}$ was assigned to the asymmetric stretch vibration of $\mathrm{P}-\mathrm{O}$, and the peak at $560 \mathrm{~cm}^{-1}$ was related to the vibration of $\mathrm{O}-\mathrm{P}-\mathrm{O} .^{35} \mathrm{It}$ is noteworthy that, the La$O$ coordination peak vibration was found at $484 \mathrm{~cm}^{-1}$ on $\mathrm{La}^{0.005} @ \mathrm{Fe} / \mathrm{C}-\mathrm{A}$, which possibly happened due to the reaction between the La and the oxygen anion in the phosphate molecule. ${ }^{36}$ Furthermore, the bands at $1068 \mathrm{~cm}^{-1}$ became stronger after adsorbing phosphate, suggesting the existence of $\mathrm{PO}_{4}{ }^{3-}$ on $\mathrm{La}^{0.005} @ \mathrm{Fe} / \mathrm{C}-\mathrm{A} .{ }^{37}$

\subsection{Batch experiments}

3.2.1 Effect of adsorbent dosage. The effect of adsorbent dosage on phosphate adsorption was studied with adsorbent dosages ranging from 1 to $8 \mathrm{~g} \mathrm{~L}^{-1}$ in $10 \mathrm{mg} \mathrm{L}^{-1}$ phosphate solution, and the results were shown in Fig. 5. As can be seen,

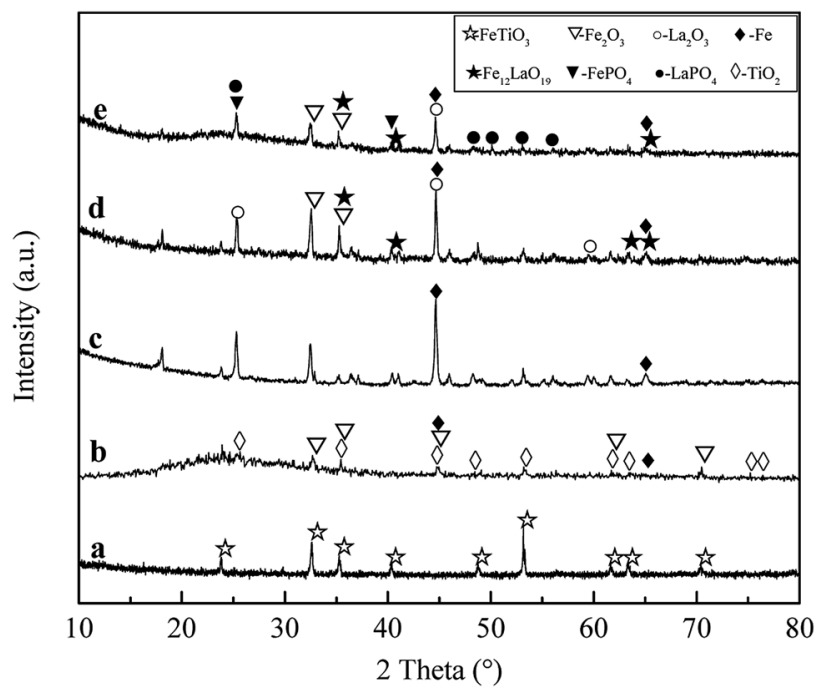

Fig. 2 XRD patterns of (a) ilmenite, (b) Fe/C precursor, (c) magnetic precursor, (d) La ${ }^{0.005} \mathrm{aFe} / \mathrm{C}$, and (e) La ${ }^{0.005} \mathrm{aFe} / \mathrm{C}-\mathrm{A}$. 

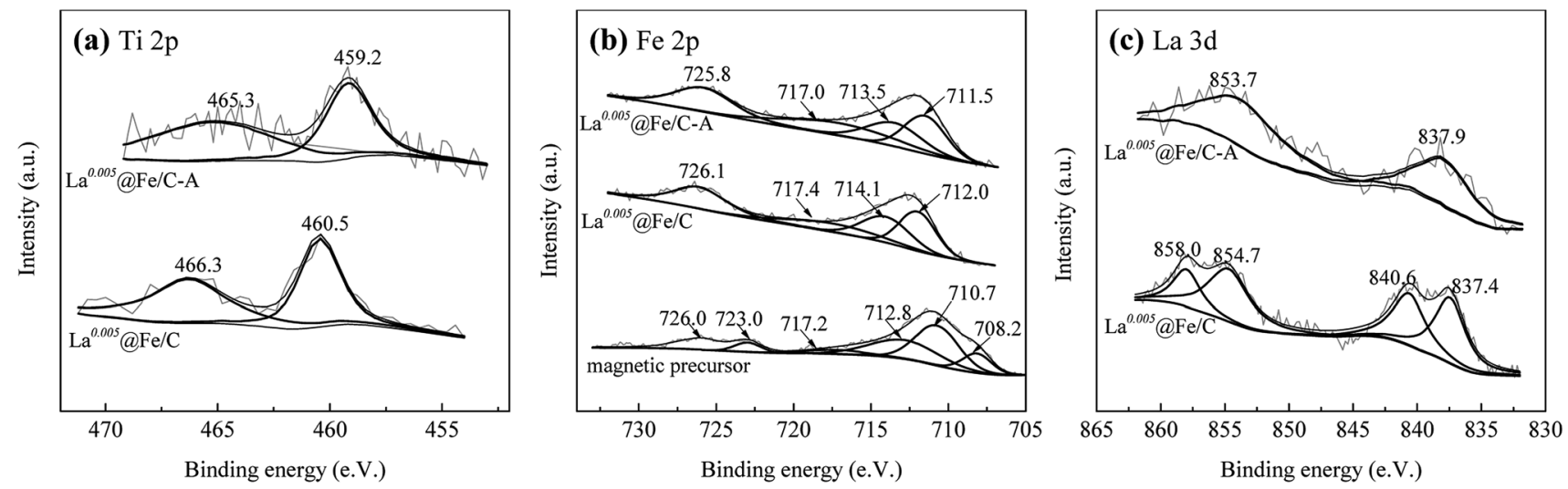

Fig. 3 XPS spectra of (a) Ti 2p, (b) Fe 2p, and (c) La 3d patterns for magnetic precursor, La ${ }^{0.005} \mathrm{aFe} / \mathrm{C}$ and La $a^{0.005} \mathrm{aFe} / \mathrm{C}-\mathrm{A}$.

$\mathrm{La}^{0.005} @ \mathrm{Fe} / \mathrm{C}$ showed substantially higher phosphate adsorption capacity, in particular at the lower range of adsorbent dosages, when compared to the coconut shell based activated carbon (AC) and ilmenite. This high phosphate adsorption capacity of $\mathrm{La}^{0.005} @ \mathrm{Fe} / \mathrm{C}$ can be attributed to the reaction of phosphate with lanthanum and iron located on the surface of the adsorbent, and thus, formation of insoluble phosphate complex, as per shown by the XRD, XPS and FTIR results. The removal efficiency of phosphate by $\mathrm{La}^{0.005} \mathrm{aFe} / \mathrm{C}$ increased from $72.0 \%$ to $93.3 \%$ with the increasing dosage of $\mathrm{La}^{0.005} @ \mathrm{Fe} / \mathrm{C}$ from $1 \mathrm{~g} \mathrm{~L}^{-1}$ to $8 \mathrm{~g} \mathrm{~L}^{-1}$, this was because higher dosage of adsorbents enabled more active sites for phosphate removal. However, the phosphate adsorption amount decreased from $7.20 \mathrm{mg} \mathrm{g}^{-1}$ to $1.17 \mathrm{mg} \mathrm{g}^{-1}$ with the dosage increasing from $1 \mathrm{~g}$ $\mathrm{L}^{-1}$ to $8 \mathrm{~g} \mathrm{~L}^{-1}$, which might possibly stem from the overlapping of available activated sites on the adsorbent. Thus, the dosage of adsorbents with $1 \mathrm{~g} \mathrm{~L}^{-1}$ was selected for the further phosphate removal experiments.

3.2.2 Effect of contact time. The effects of contact time on $\mathrm{AC}$, ilmenite and $\mathrm{La}^{0.005} @ \mathrm{Fe} / \mathrm{C}$ are presented in Fig. 6. Ilmenite

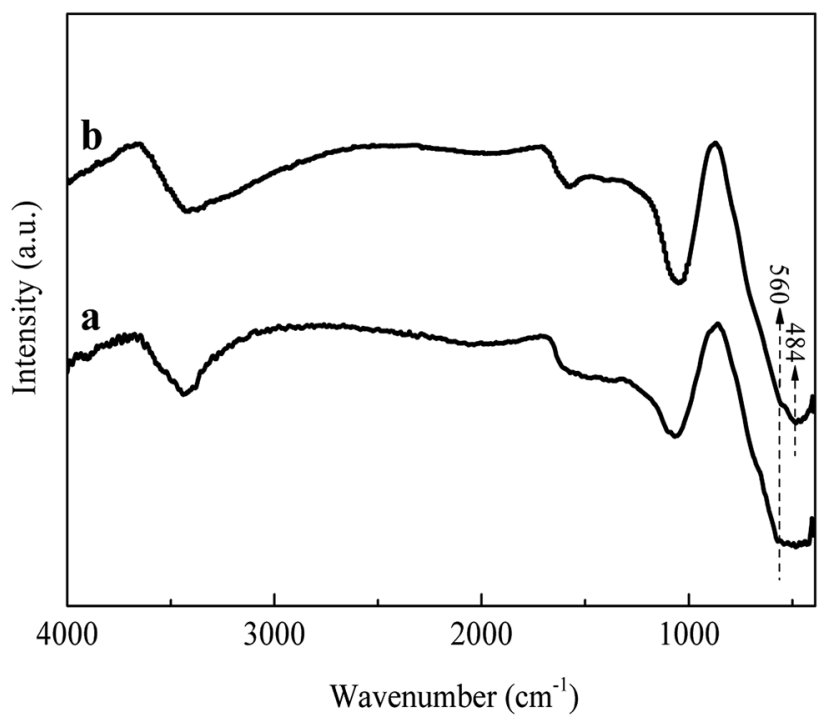

Fig. 4 FTIR spectra of (a) La ${ }^{0.005} \mathrm{aFe} / \mathrm{C}$ and (b) La ${ }^{0.005} \mathrm{aFe} / \mathrm{C}-\mathrm{A}$. and $\mathrm{La}^{0.005} @ \mathrm{Fe} / \mathrm{C}$ showed fast adsorption within the initial $30 \mathrm{~min}$, and then the adsorption process gradually slowed down and reached equilibrium at nearly $90 \mathrm{~min}$, while the equilibrium time for $\mathrm{AC}$ was around $120 \mathrm{~min}$. This was because at initial stage, large amount of vacant adsorption sites was available on the surface and internal structure of AC, ilmenite and $\mathrm{La}^{0.005} \mathrm{OFe} / \mathrm{C}$. As the adsorption process continued, the active sites on the adsorbents gradually saturated and hardly adsorb phosphate. ${ }^{8}$ As shown in Table $1, \mathrm{AC}, \mathrm{Fe} / \mathrm{C}$ precursor, and $\mathrm{La}^{0.005} @ \mathrm{Fe} / \mathrm{C}$ presented microporosity in the order of $\mathrm{AC}>$ $\mathrm{Fe} / \mathrm{C}$ precursor $>\mathrm{La}^{0.005} @ \mathrm{Fe} / \mathrm{C}$, whereas the adsorption capacities for the removal of phosphate is in the order of $\mathrm{La}^{0.005} @ \mathrm{Fe} /$ $\mathrm{C}>\mathrm{Fe} / \mathrm{C}$ precursor $>\mathrm{AC}$, which could be due to different chemical properties of these adsorbents. Upon a three-hourlong exposure, $\mathrm{La}^{0.005} \mathrm{Ge} / \mathrm{C}$ exhibited higher phosphate capacity $\left(7.36 \mathrm{mg} \mathrm{g}^{-1}\right)$ when compared to AC $\left(2.27 \mathrm{mg} \mathrm{g}^{-1}\right)$ and $\mathrm{Fe} / \mathrm{C}$ precursor $\left(5.71 \mathrm{mg} \mathrm{g}^{-1}\right)$, as shown in Fig. 6 The stronger adsorptive performance of $\mathrm{La}^{0.005} @ \mathrm{Fe} / \mathrm{C}$ towards phosphate can be attributable to the more active sites available on the surface of $\mathrm{La}^{0.005} @ \mathrm{Fe} / \mathrm{C}$, as compared to the $\mathrm{Fe} / \mathrm{C}$ precursor and $\mathrm{AC}$.

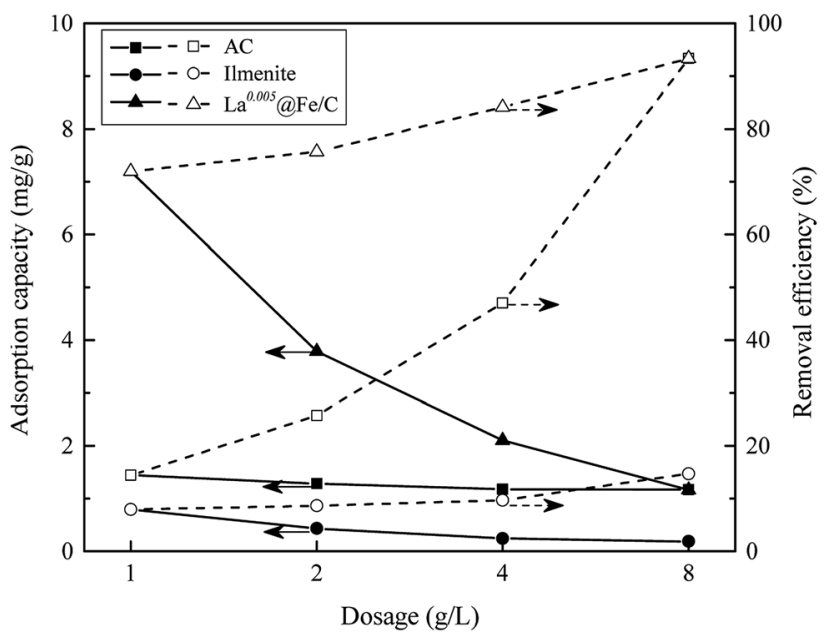

Fig. 5 Influences of different adsorbent dosages on phosphate adsorption and removal efficiency of different adsorbents. 
3.2.3 Effect of $\mathbf{p H}$. Another important factor to be taken into consideration is the $\mathrm{pH}$ of the solution, which can affect both the degree of adsorbate ionization and the surface charge of the adsorbent in the solution. The influence of $\mathrm{pH}$ on the removal of phosphate by $\mathrm{La}^{0.005} @ \mathrm{Fe} / \mathrm{C}$ was investigated at different $\mathrm{pH}$ values ranging from 3 to 11 , and the results are shown in Fig. 7. It can be seen that a pH increases from 3 to 7 yielded a higher uptake of phosphate, whereby the maximum phosphate adsorption amount was achieved at $\mathrm{pH}=7$. It was reported that within the $\mathrm{pH}$ range of $3-8, \mathrm{H}_{2} \mathrm{PO}_{4}{ }^{-}$is the dominant phosphate species in the solution. ${ }^{6}$ Since the zero point of charge $\left(\mathrm{pH}_{\mathrm{pzc}}\right)$ of $\mathrm{La}^{0.005}$ @Fe/C is 7.45 , a $\mathrm{pH}$ value lower than 7.45 causes the surface of $\mathrm{La}^{0.005} @ \mathrm{Fe} / \mathrm{C}$ to become positively charged, which further favors the electrostatic interaction and ion exchange with $\mathrm{H}_{2} \mathrm{PO}_{4}{ }^{-}$. As the $\mathrm{pH}$ value increased further from 7 to 11 , the adsorption capacity decreased from $7.28 \mathrm{mg}$ $\mathrm{g}^{-1}$ to $6.70 \mathrm{mg} \mathrm{g}^{-1}$. This was mainly caused by the fact that alkaline $\mathrm{pH}$ generates repulsive electrostatic forces, weakening the active adsorption sites for ion exchange due to the high concentration of $\mathrm{OH}^{-}$in the solution. ${ }^{38}$

\subsection{Adsorption mechanism}

3.3.1 Adsorption kinetics. The kinetic modeling were fitted to the pseudo-first-order, pseudo-second-order model and intraparticle diffusion. Results (see Fig. 8 and Table 2) showed that the experimental kinetic data can be best described by pseudosecond-order model with $R^{2}$ for AC, precursor and $\mathrm{La}^{0.005} @ \mathrm{Fe} / \mathrm{C}$ were $0.9908,0.9996$ and 0.9998 , respectively. The calculated $q_{\mathrm{e}}$ values $\left(q_{\mathrm{e}, \mathrm{cal}}=2.32,5.74,7.44 \mathrm{mg} \mathrm{g}^{-1}\right.$ for AC, precursor and $\mathrm{La}^{0.005} @ \mathrm{Fe} / \mathrm{C}$, respectively) were in well agreement with the experimental values $\left(q_{\mathrm{e}, \exp }=2.27,5.71,7.36 \mathrm{mg} \mathrm{g}^{-1}\right.$ for AC, precursor and $\mathrm{La}^{0.005} @ \mathrm{Fe} / \mathrm{C}$, respectively). These results confirmed that the phosphate adsorption process might be controlled by the chemisorption process. ${ }^{39}$ For a better understanding of the adsorption mechanism, intra-particle-diffusion model was further applied to fit the experimental data. As can



Fig. 6 Influences of contact time on the phosphate adsorption of AC $\mathrm{Fe} / \mathrm{C}$ precursor and $\mathrm{La}^{0.005} \mathrm{aFe} / \mathrm{C}$. be seen from Fig. 8, the adsorption kinetics curve of intraparticle-diffusion model can be divided into two major phases, the first phase showed a higher rate constant $K_{\mathrm{id} 1}$ of $\mathrm{La}^{0.005} @ \mathrm{Fe} / \mathrm{C}$, which indicated a higher removal rate in the beginning due to the large available surface area and high amount of active sites on the external surface. ${ }^{17}$ The lower use of $K_{\mathrm{id} 2}$ could be related to the smaller amount of adsorption sites on the adsorbent, limiting the intra particle diffusion. It is noteworthy that the plot did not pass through the origin, which suggests that intra-particle-diffusion was not the key step to control the adsorption process. Some other mechanisms such as initial external mass transfer may also be involved in the phosphate adsorption process. $^{40}$

3.3.2 Adsorption isotherms. The equilibrium data were fitted to the Langmuir, Freundlich and Temkin isotherm models (Fig. 9), and the adsorption constants were presented in Table 3. The adsorption of phosphate onto $\mathrm{La}^{0.005} @ \mathrm{Fe} / \mathrm{C}$ fitted best to Langmuir model $\left(R^{2}=0.9980\right)$, suggesting that the adsorption of phosphate on $\mathrm{La}^{0.005} @ \mathrm{Fe} / \mathrm{C}$ was based on monolayer homogeneous adsorption process. It could be seen from Table 3 that the $q_{\mathrm{e}}$ of $\mathrm{La}^{0.005} @ \mathrm{Fe} / \mathrm{C}$ calculated from the Langmuir model increased from $32.16 \mathrm{mg} \mathrm{g}^{-1}$ at $293 \mathrm{~K}$ to $39.90 \mathrm{mg} \mathrm{g}^{-1}$ at $323 \mathrm{~K}$, indicating that the adsorption of phosphate onto $\mathrm{La}^{0.005} @ \mathrm{Fe} / \mathrm{C}$ was an endothermic process. ${ }^{41}$ The value of $k_{\mathrm{L}}$, calculated from Langmuir isotherm was 0.08-0.10, suggesting a favorable adsorption of phosphate on $\mathrm{La}^{0.005} @ \mathrm{Fe} /$ C. In addition, the value of $n$ calculated from Freundlich model is 1.88 , pointing to a chemically favorable and heterogeneous adsorption of phosphate onto $\mathrm{La}^{0.005} @ \mathrm{Fe} / \mathrm{C} .^{42}$ The Temkin constant $b$ was related to the heat of adsorption, and its values were positive for all temperatures $\left(b=321.84 \mathrm{~J} \mathrm{~mol}^{-1}\right.$ at $\left.293 \mathrm{~K}\right)$, which also confirms the fact that adsorption of phosphate onto $\mathrm{La}^{0.005} @ \mathrm{Fe} / \mathrm{C}$ was endothermic process. ${ }^{43}$

3.3.3 Thermodynamic analysis. Thermodynamic parameters for phosphate adsorption onto $\mathrm{La}^{0.005} @ \mathrm{Fe} / \mathrm{C}$ were evaluated at $293 \mathrm{~K}, 303 \mathrm{~K}, 313 \mathrm{~K}$ and $323 \mathrm{~K}$ using eqn (10) and (11). The positive value of $\Delta H^{0}\left(3.40 \mathrm{~kJ} \mathrm{~mol}^{-1}\right)$ indicates that phosphate

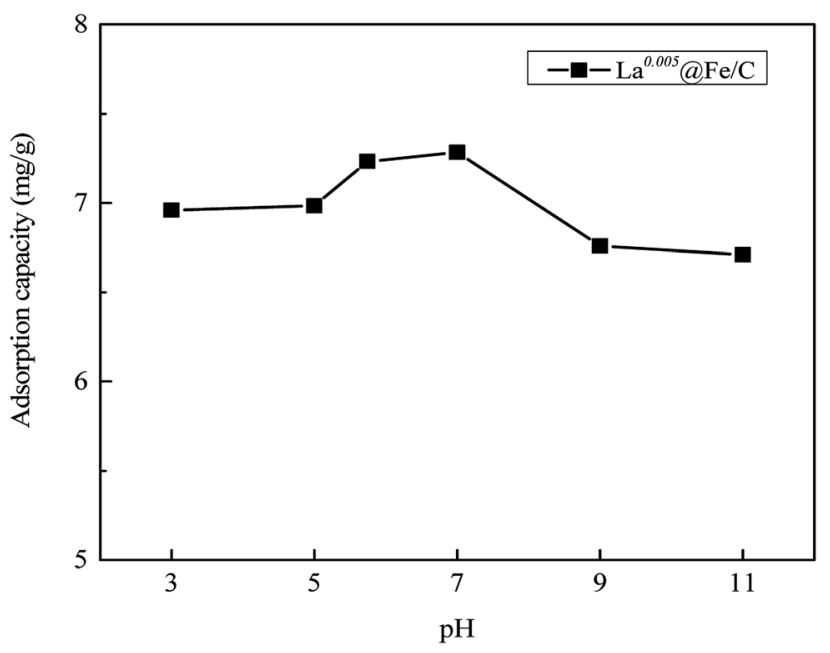

Fig. 7 Influences of $\mathrm{pH}$ on phosphate adsorption by $\mathrm{La}^{0.005} \mathrm{aFe} / \mathrm{C}$. 

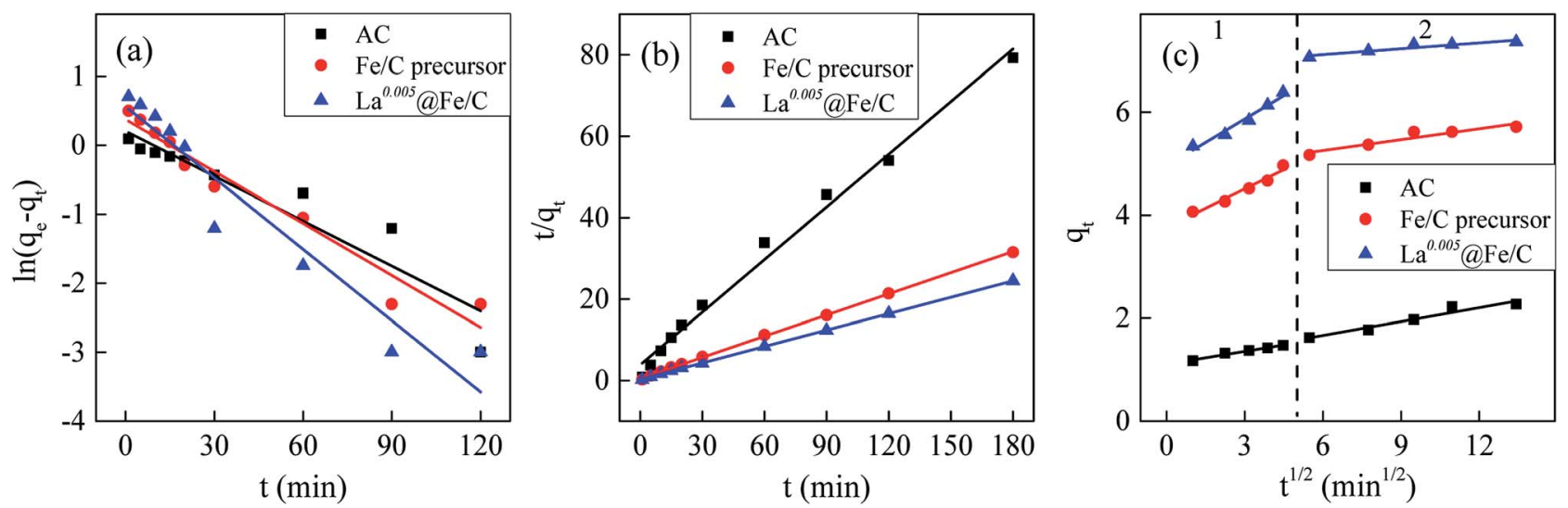

Fig. 8 Kinetic modeling of: (a) pseudo-first-order model, (b) pseudo-second-order model, and (c) intra-particle diffusion model for phosphate adsorption on the adsorbents.

adsorption onto $\mathrm{La}^{0.005} \mathrm{@Fe} / \mathrm{C}$ is an endothermic process, while the negative values of $\Delta G^{0}\left(-2.44 \mathrm{~kJ} \mathrm{~mol}^{-1},-2.64 \mathrm{~kJ} \mathrm{~mol}^{-1}\right.$, $-2.84 \mathrm{~kJ} \mathrm{~mol}^{-1}$, and $-3.04 \mathrm{~kJ} \mathrm{~mol}^{-1}$ ) at temperature of $293 \mathrm{~K}$, $303 \mathrm{~K}, 313 \mathrm{~K}$ and $323 \mathrm{~K}$, respectively, indicated the phosphate adsorption occurs spontaneously. ${ }^{44}$ The positive value $\Delta S^{0}$ $\left(0.02 \mathrm{~kJ} \mathrm{~mol}^{-1} \mathrm{~K}^{-1}\right.$ ) showed the affinity of $\mathrm{La}^{0.005} @ \mathrm{Fe} / \mathrm{C}$ for adsorbing phosphate and the increasing randomness at the solid-solution interface with some structural changes in the adsorbates and adsorbents during the adsorption process. ${ }^{45}$

\subsection{Influence of coexisting ion}

The influence of coexisting ions in waste water such as $\mathrm{NO}_{3}{ }^{-}$, $\mathrm{Cl}^{-}, \mathrm{CO}_{3}{ }^{2-}, \mathrm{SO}_{4}{ }^{2-}$ and $\mathrm{Ca}^{2+}$ (ref. 46$)$ on phosphate $\left(10 \mathrm{mg} \mathrm{L}^{-1}\right.$ ) adsorption was investigated, and the results are presented in Fig. 10. It can be observed from Fig. 10 that high concentration (500 $\mathrm{mg} \mathrm{L}^{-1}$ ) of anion $\mathrm{Cl}^{-}$and cation $\mathrm{Ca}^{2+}$ hardly affected the removal of phosphate, whereas the presence of $\mathrm{NO}_{3}{ }^{-}, \mathrm{CO}_{3}{ }^{2-}$ and $\mathrm{SO}_{4}{ }^{2-}$ resulted in slightly decreased phosphate removal, leading to a decreased phosphate removal from $73.08 \%$ to

Table 2 Kinetic parameters for removal of phosphate by AC, Fe/C precursor and $\mathrm{La}^{0.005} \mathrm{aFe} / \mathrm{C}$

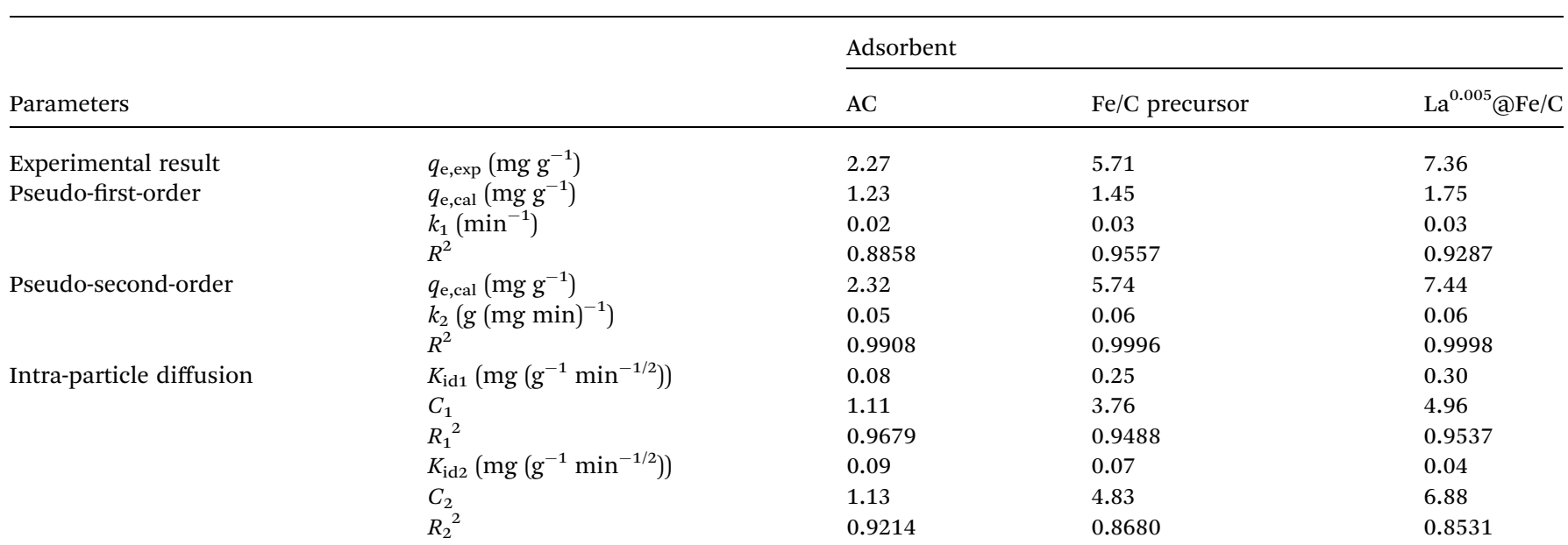

Table 3 Isotherm parameters for the adsorption of phosphate by $\mathrm{La}^{0.005} \mathrm{aFe} / \mathrm{C}$

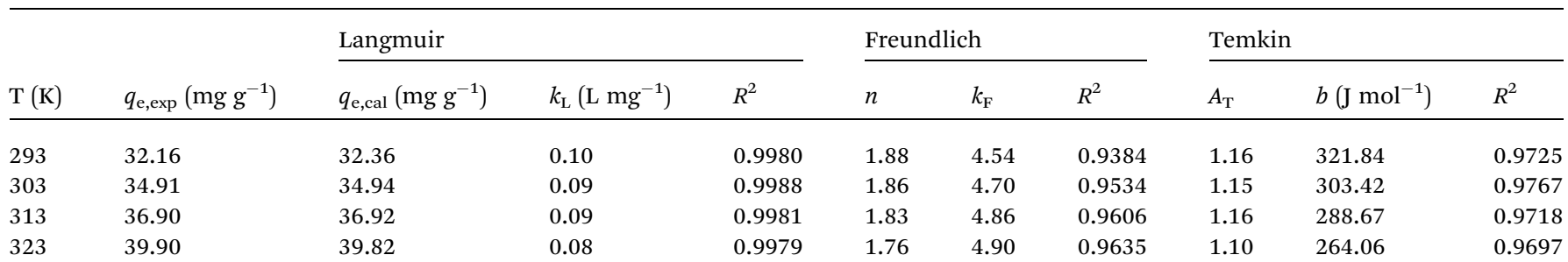



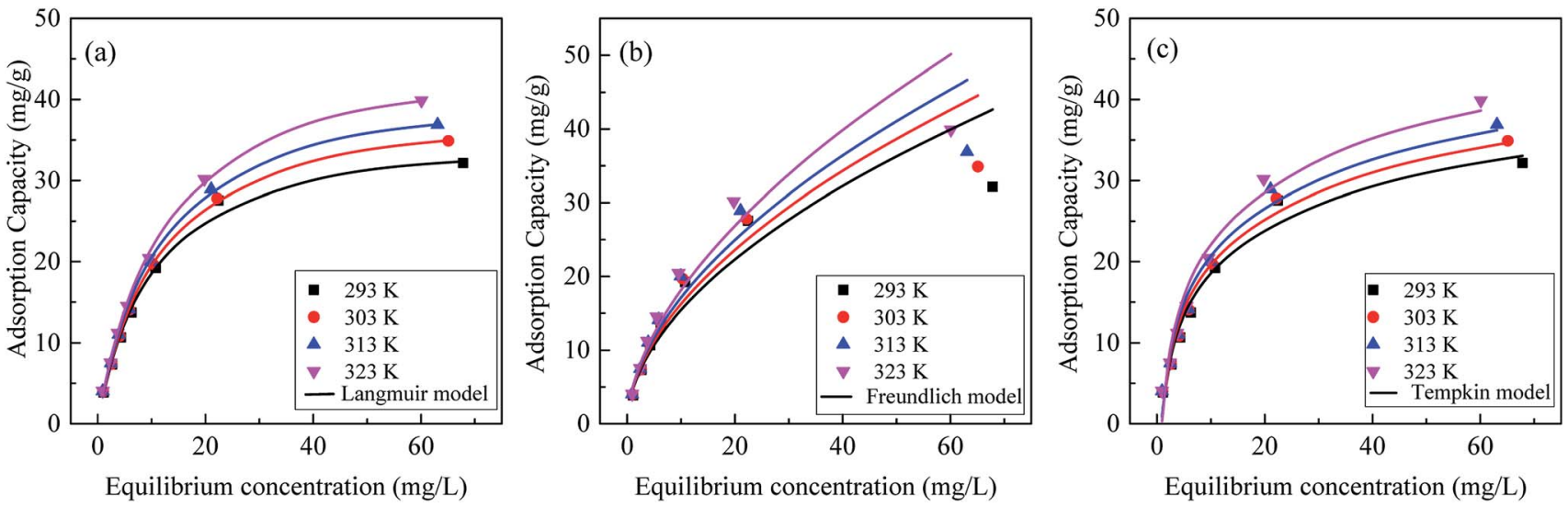

Fig. 9 Isotherm modeling of (a) Langmuir, (b) Freundlich, and (c) Temkin adsorption isotherms for phosphate adsorption on La.005 $a$ Fe/C.

$55.86 \%, 53.62 \%$ and $62.85 \%$, respectively. This slight decrement of phosphate adsorption capacity in the presence of coexisting anions could stem from the fact that anions can act as a competition ion, inducing electrostatic repulsion between the deprotonated surface hydroxyls and the highly charged $\mathrm{PO}_{4}{ }^{3-}$. The reduction of phosphate adsorption in the presence of $\mathrm{CO}_{3}{ }^{2-}$ was relatively more obvious, which might be due to the formation of $\mathrm{La}_{2}\left(\mathrm{CO}_{3}\right)_{3}$, for it has a lower $K_{\mathrm{SP}}\left(3.98 \times 10^{-34}\right)$ than $\mathrm{LaPO}_{4}\left(3.70 \times 10^{-23}\right) .{ }^{54}$ It can be noticed that the removal of phosphate was effective ( $>53.62 \%$ removal efficiency) even in the presence of coexisting ions with 50 -fold excess, indicating $\mathrm{La}^{0.005} @ \mathrm{Fe} / \mathrm{C}$ had a high adsorption selectivity towards phosphate.

\subsection{The stability and reusability of $\mathrm{La}^{0.005} @ \mathrm{Fe} / \mathrm{C}$}

To assess the reusability of $\mathrm{La}^{0.005}$ @Fe/C, a series of experiments have been devised, whereby the adsorbent is exposed to thermal regeneration and five cycles of repeated adsorption and regeneration. The performance of the reused $\mathrm{La}^{0.005} @ \mathrm{Fe} / \mathrm{C}$ with respect to the adsorptive removal of phosphate is shown in

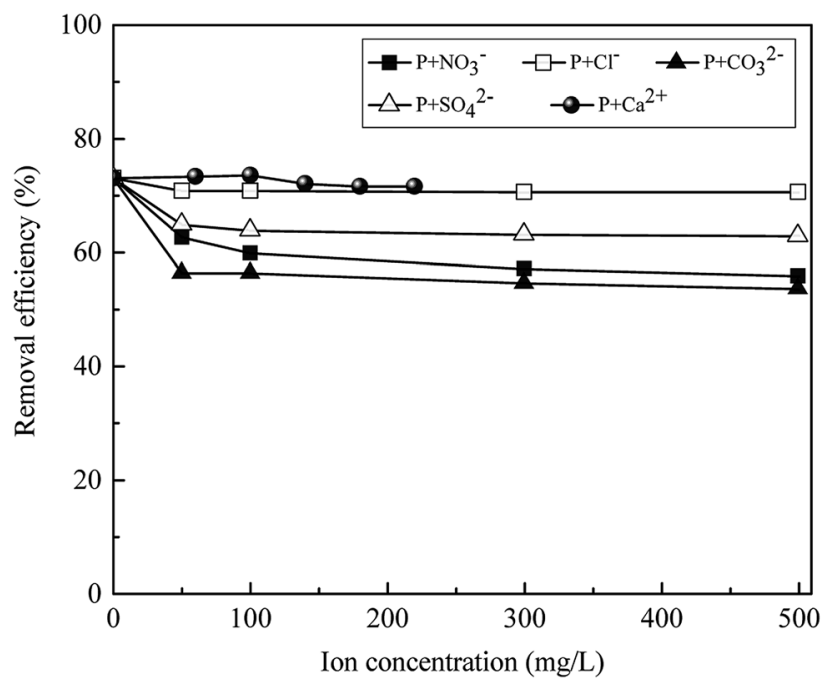

Fig. 10 The effect of $\mathrm{NO}_{3}{ }^{-}, \mathrm{Cl}^{-}, \mathrm{CO}_{3}{ }^{2-}, \mathrm{SO}_{4}{ }^{2-}$ and $\mathrm{Ca}^{2+}$ on phosphate adsorption of $\mathrm{La}^{0.005} \mathrm{aFe} / \mathrm{C}$.
Fig. 11. A gradual decrease from $7.20 \mathrm{mg} \mathrm{g}^{-1}$ to $4.20 \mathrm{mg} \mathrm{g}^{-1}$ was observed in the phosphate removal capacity, which corresponds to a capacity retention of $58.33 \%$ after five cycles. Nonetheless, the adsorbent exhibited higher stability than the previously reported phosphate adsorbents, i.e., $\mathrm{La}(\mathrm{OH})_{3} / \mathrm{Fe}_{3} \mathrm{O}_{4} \quad(4: 1)$ nanocomposite, and $\mathrm{La}$ based $\mathrm{FeCl}_{3} / \mathrm{LSF}$ (lithium silica fume). ${ }^{10,55}$ Therefore, the La@Fe/C particle in this work is considered as a promising phosphate adsorbent with high stability and removal efficiency.

\subsection{Comparison with various adsorbents}

Table 4 presented the comparison of theoretical phosphate adsorption capacity of $\mathrm{La}^{0.005} @ \mathrm{Fe} / \mathrm{C}$ with various adsorbents based on Langmuir isotherm. It can be seen that the phosphate adsorption capacity of $\mathrm{La}^{0.005} @ \mathrm{Fe} / \mathrm{C}$ is relatively higher than the other adsorbents reported in the literature. Similarly, other bimetallic adsorbents such as Fe-Mn binary oxide and ACFLaFe reportedly exhibited high phosphate adsorption capacities of $33.20 \mathrm{mg} \mathrm{g}^{-1}$ and $29.44 \mathrm{mg} \mathrm{g}^{-1}$, respectively. These high values are associated with the fact that by coupling two metal

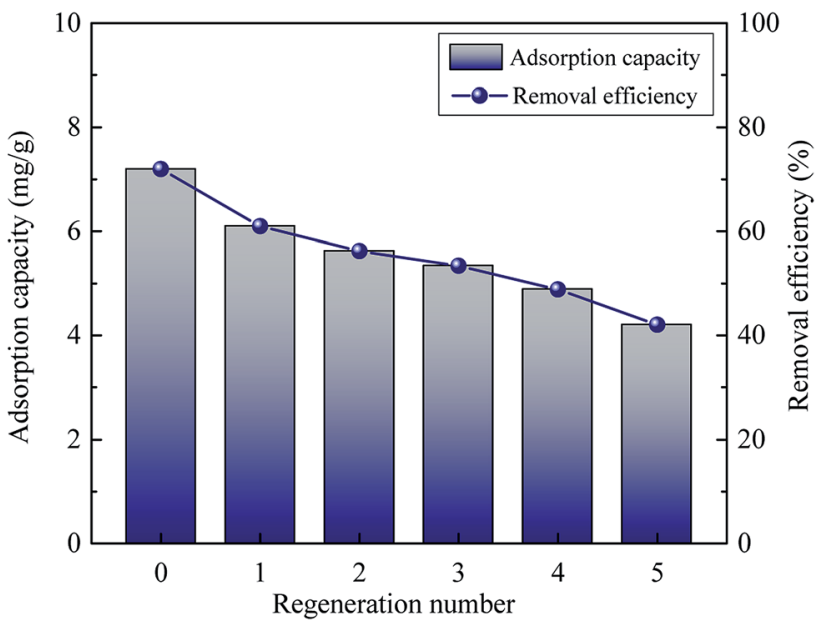

Fig. 11 Phosphate adsorption capacity and removal efficiency of $\mathrm{La}^{0.005} \mathrm{aFe} / \mathrm{C}$ as a function of adsorption-regeneration cycles. 
Table 4 Comparison of phosphate adsorption capacity of various adsorbents

\begin{tabular}{|c|c|c|c|}
\hline Adsorbent & $\begin{array}{l}\text { Temperature } \\
\text { (K) }\end{array}$ & $\begin{array}{l}\text { Adsorption capacity } \\
\left(\mathrm{mg} \mathrm{g}^{-1}\right)\end{array}$ & Reference \\
\hline $\mathrm{La}^{0.005} @ \mathrm{Fe} / \mathrm{C}$ & 293 & 32.36 & This work \\
\hline Iron oxide tailings & 293 & 8.21 & 48 \\
\hline $\mathrm{AC} / \mathrm{N}-\mathrm{Fe}^{(\mathrm{II})}$ & 298 & 14.12 & 49 \\
\hline $\mathrm{AC} / \mathrm{N}-\mathrm{Fe}^{(\mathrm{III})}$ & 298 & 8.13 & 49 \\
\hline Granular ferric hydroxide & 294 & 20.9 & 52 \\
\hline ACF-LaFe & 298 & 29.44 & 8 \\
\hline $\mathrm{Fe}_{3} \mathrm{O}_{4} @ \mathrm{La}-\mathrm{Ce}$ & 313 & 19.6 & 53 \\
\hline $\mathrm{Fe}_{3} \mathrm{O}_{4}$ nanoparticles & 296 & 4.50 & 10 \\
\hline Magnetic & 296 & 27.80 & 10 \\
\hline $\mathrm{Fe}_{3} \mathrm{O}_{4} @ \mathrm{SiO}_{2} @ \mathrm{La}_{2} \mathrm{O}_{3}$ & & & \\
\hline
\end{tabular}

species, the adsorbent interface could be engineered to possess multiple sites which then contribute to binding phosphate. ${ }^{56}$

\section{Conclusions}

A novel 3D flower-like La@Fe/C magnetic composite adsorbent was successfully prepared by carbothermal reduction of ilmenite via microwave radiation. The resultant $\mathrm{La}^{0.005} @ \mathrm{Fe} / \mathrm{C}$ features active adsorption sites for phosphate uptake even in the presence of 50-fold excess competing ions. The phosphate adsorption on $\mathrm{La}^{0.005} @ \mathrm{Fe} / \mathrm{C}$ fitted well to Langmuir mode, with the calculated maximum adsorption capacity of $32.36 \mathrm{mg} \mathrm{g}^{-1}$ at $293 \mathrm{~K}$. Thermodynamic study indicated that the adsorption of phosphate occurs spontaneously and endothermically. Regeneration tests showed the $\mathrm{La} @ \mathrm{Fe} / \mathrm{C}$ composite is a potentially attractive adsorbent for the removal of phosphate from aqueous solutions with high efficiency and recycling capability.

\section{Conflicts of interest}

There are no conflicts to declare.

\section{Acknowledgements}

The authors acknowledge the funding support from the National Natural Science Foundation of China (51808360), China Postdoctoral Science Foundation (2018M640917), Chengdu Science and Technology Department (2019-GH0200053-HZ). We would also like to thank the support for teacher Wang Dong (SEM analysis) from Analytical \& Testing center of Sichuan University.

\section{Notes and references}

1 X. T. Zhang, W. Wang, S. Y. Dai and F. Y. Cui, RSC Adv., 2018, 8, 11754-11763.

2 L. Paripurnanda, V. Saravanamuthu, K. Jaya and S. B. Nanthi, Crit. Rev. Environ. Sci. Technol., 2014, 44, 847907.
3 B. Hui, Y. Zhang and L. Ye, Chem. Eng. J., 2014, 235, 207-214. 4 S. X. Dong, Y. L. Wang, Y. W. Zhao, X. H. Zhou and H. L. Zheng, Water Res., 2017, 126, 433-441.

5 L. E. De-Bashan and Y. Bashan, Water Res., 2004, 38, 42224246.

6 R. Z. Xie, Y. Chen, T. Cheng, Y. G. Lai, W. J. Jiang and Z. S. Yang, Water Sci. Technol., 2016, 73, 1891-1900.

7 J. Yang, L. Zhou, L. Z. Zhao, H. W. Zhang, J. N. Yin, G. F. Wei, K. Qian, Y. H. Wang and C. Z. Yu, J. Mater. Chem., 2011, 21, 2489-2494.

8 J. Liu, Q. Zhou, J. Chen, L. Zhang and N. Chang, Chem. Eng. J., 2013, 215-216, 859-867.

9 Z. Wang, Y. Fan, Y. W. Li, F. R. Qu, D. Y. Wu and H. N. Kong, Microporous Mesoporous Mater., 2016, 222, 226-234.

10 B. L. Wu, L. P. Fang, J. D. Fortner, X. H. Guan and I. M. C. Lo, Water Res., 2017, 126, 179-188.

11 J. C. Liu, I. Warmadewanthi and C. Chang, Colloids Surf., A, 2009, 347, 215-219.

12 X. Jiang, Y. H. Guo, L. B. Zhang, W. J. Jiang and R. Z. Xie, Chem. Eng. J., 2018, 341, 392-401.

13 M. J. Lehtinen, in Mineral Deposits of Finland, ed. W. D. Maier, R. Lahtinen and H. O'Brien, Elsevier, 2015, pp. 685710, DOI: 10.1016/B978-0-12-410438-9.00026-1.

14 L. Lai, Q. Xie, L. N. Chi, W. Gu and D. Y. Wu, J. Colloid Interface Sci., 2016, 465, 76.

15 S. Lagergren, K. Sven. Vetenskapsakad. Handl., 1989, 24, 1-39. 16 R. Z. Xie, H. Wang, Y. Chen and W. J. Jiang, Environ. Prog. Sustainable Energy, 2013, 32, 688-696.

17 H. Wang, R. Z. Xie, J. Zhang and J. Zhao, Adv. Powder Technol., 2017, 29, 27-35.

18 J. W. McBain, J. Phys. Chem., 1934, 39, 1162.

19 I. Langmuir, J. Chem. Phys., 2015, 40, 1361-1403.

20 X. B. Luo, W. Xing, R. Zhong, X. Y. Min, X. Xiao and J. M. Luo, Ind. Eng. Chem. Res., 2017, 56, 9419-9428.

21 X. B. Luo, K. Zhang, J. M. Luo, S. L. Luo and J. Crittenden, Environ. Sci. Technol., 2016, 50, 13002-13012.

22 S. Moharami and M. Jalali, Chem. Eng. J., 2013, 223, 328-339. 
23 Z. P. Wen, Y. L. Zhang, C. M. Dai, B. Chen, S. J. Guo, H. Yu and D. L. Wu, Microporous Mesoporous Mater., 2014, 200, 235-244.

24 B. Tansel, J. Sager, T. Rector, J. Garland, R. F. Strayer, L. Levine, M. Roberts, M. Hummerick and J. Bauer, Sep. Purif. Technol., 2006, 51, 40-47.

25 P. C. Wang, X. Jiang, C. J. Zhang, Q. Y. Zhou, J. J. Li and W. J. Jiang, Energy Fuels, 2017, 31, 5266-5274.

26 N. J. Welham, Metall. Mater. Trans. A, 2000, 31, 283-289.

27 C. J. Zhang, D. N. Yang, X. Jiang and W. J. Jiang, Environ. Technol., 2015, 37, 1895-1905.

28 M. Murata, K. Wakino and S. Ikeda, J. Electron Spectrosc. Relat. Phenom., 1975, 6, 459-464.

29 G. C. Bond and S. Flamerz, Appl. Catal., 1989, 46, 89-102.

30 I. Georgiadou, N. Spanos, C. Papadopoulou, H. Matralis, C. Kordulis and A. Lycourghiotis, Colloids Surf., A, 1995, 98, 155-165.

31 J. Leveneur, G. I. N. Waterhouse, J. Kennedy, J. B. Metson and D. R. G. Mitchell, J. Phys. Chem. C, 2011, 115, 2097820985.

32 X. Gao, S. Liu, Y. Zhang, Z. Luo and K. Cen, J. Hazard. Mater., 2011, 188, 58-66.

33 J. Wang, L. Y. Wu, J. Li, D. Tang and G. K. Zhang, J. Alloys Compd., 2018, 753, 422-432.

34 Q. S. Liu, Z. Tong, L. Nan, W. Peng and G. Abulikemu, Appl. Surf. Sci., 2010, 256, 3309-3315.

35 J. J. He, W. Wang, W. X. Shi and F. Y. Cui, RSC Adv., 2016, 6, 99353-99360.

36 L. Zhang, Q. Zhou, J. Y. Liu, N. Chang, L. H. Wan and J. H. Chen, Chem. Eng. J., 2012, 185-186, 160-167.

37 H. R. Nodeh, H. Sereshti, E. Z. Afsharian and N. Nouri, J. Environ. Manage., 2017, 197, 265-274.

38 J. Goscianska, M. Ptaszkowska-Koniarz, M. Frankowski, M. Franus, R. Panek and W. Franus, J. Colloid Interface Sci., 2018, 513, 72-81.
39 M. Kılıç, Ç. Kırbıyık, Ö. Çepelioğullar and A. E. Pütün, Appl. Surf. Sci., 2013, 283, 856-862.

40 W. Liu, Z. Cai, X. Zhao, T. Wang, F. Li and D. Zhao, Environ. Sci. Technol., 2016, 50, 11174-11183.

41 J. M. Salman, V. Njoku and B. H. Hameed, Chem. Eng. J., 2011, 174, 33-40.

42 N. Asanjarani, Desalin. Water Treat., 2015, 53, 430-445.

43 S. Mor, K. Chhoden, P. Negi and K. Ravindra, Environ. Nanotechnol. Monit., 2017, 7, 15-23.

44 Z. H. Wang, D. K. Shen, F. Shen and T. Y. Li, Chemosphere, 2016, 150, 1-7.

45 F. Nekouei, S. Nekouei, I. Tyagi and V. K. Gupta, J. Mol. Liq., 2015, 201, 124-133.

46 D. D. Tang and G. K. Zhang, Chem. Eng. J., 2016, 283, 721729.

47 S. Kilpimaa, H. Runtti, T. Kangas, U. Lassi and T. Kuokkanen, J. Ind. Eng. Chem., 2015, 21, 1354-1364.

48 L. Zeng, X. M. Li and J. D. Liu, Water Res., 2004, 38, 13181326.

49 Z. F. Wang, E. Nie, J. H. Li, M. Yang, Y. J. Zhao, X. Z. Luo and Z. Zheng, Environ. Sci. Pollut. Res., 2011, 19, 2908-2917.

50 P. Ning, H.-J. Bart, B. Li, X. W. Lu and Y. Zhang, J. Environ. Sci., 2008, 20, 670-674.

51 G. Zhang, H. J. Liu, R. P. Liu and J. H. Qu, J. Colloid Interface Sci., 2009, 335, 168-174.

52 P. Suresh Kumar, L. Korving, K. J. Keesman, M. C. M. van Loosdrecht and G.-J. Witkamp, Chem. Eng. J., 2019, 358, 160-169.

53 M. Y. Han, J. H. Zhang, Y. Y. Hu and R. P. Han, J. Chem. Eng. Data, 2019, 64, 3641-3651.

54 P. Koilraj and K. Sasaki, Chem. Eng. J., 2017, 317, 1059-1068. 55 Y. G. Lai, W. J. Jiang, Z. S. Yang, X. P. Hao and R. Z. Xie, Desalin. Water Treat., 2016, 57, 1-12.

56 A. L. Mckenzie, C. T. Fishel and R. J. Davis, J. Catal., 1992, 138, 547-561. 